\title{
車いす利用者の足のむくみの問題の検証とその予防案の検討
}

\section{The analysis of dropsical swelling for wheelchair users and the method of prevention}

\section{○増子 邦夫，手嶋 教之，高橋 洋子}

\section{立命館大学大学院 理工学研究科 㓣造理工学専攻 機械システムコース 福祉工学研究室 \\ OKunio Masuko, Dept of Science \& Engineering, Graduate School of Ritsumeikan University Nor iyuki Tejima, Yoko Takahashi, Dept. Robotics, Ritsume ikan University}

\section{1. はじめに}

むくみとは日常生活に扔いて長時問のデスクワークや，夜 行バス乗車時など様々な状況で起こるが，時には飛行機搭乗 時にエコノミークラス将侯群老引き起こす要因にもなってい る.さらに車い寸利用者の場合, 長時閒座りっぱなしの状態で あるのでエコノミークラス症候群を発症してしまいこれが原 因で亡くなった例 ${ }^{11}$ も確認されている.また実際に医療現場

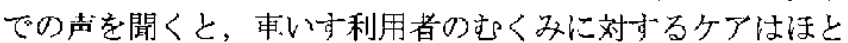
んどされておらず介護側としても1つの問題となっている. 本研究では車い寸利用者が抱えるト肢のむくみの閭題の検証 を行う上共にその予防案を検討していくこと老目的とした。

\section{2. 測定機器}

下肢のむくみを測定する装置として水銀封入式のラバース トレインゲージを用いた。これは細管に水銀を満たしたもの であり，体肢の周の脣さの変化を電気抵抗変化として検出标 る方法である。本実験ではストレインダージフォトプレスチ モグラフ (EC6. D. E. Hokanson, Inc (LSA)) を用いラバーストレ インダージの変化量 $(\%)$ を測定しむく双の変化の指標とした.

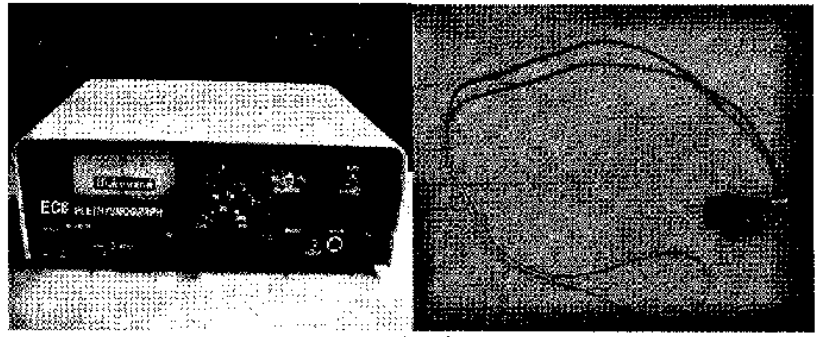

Fig. 1 测定機吠

\section{3. 寒験条件の設定}

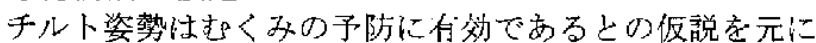
その検証索行った。

\section{1 测定部位の設定}

測定部位在考えるにあたって，足首，ふくらはぎ，足の甲 の3筒所に対して滕角度 $90^{\circ}$ ，シート・゙ックレスト角度 $90^{\circ}$ の座位姿勢（以下ノーマル姿勢と寸る）て測定老試多た。1 回の実験で 1 箘所の測定を行った。测定時間は 15 分とした。 実験結果から Table 1 の上うに評価定行った。変化比較上は 測定前上測定後の変化率の差の比較のしや寸さの事である。 これらの評価を元に，再現性が高いことや，長時間の測定が 可能であること，筋肉や血管の影䍶が出にくいことから足首 での測定が好ましいと判断した。

Table 1 测定部位が各要素に与える影響

\begin{tabular}{|c|c|c|c|}
\hline & 再現性 & 统化比較 & 測定時間 \\
\hline 足の甲 & $\times$ & $\bigcirc$ & $\times$ \\
\hline 足首 & $\bigcirc$ & $\triangle$ & $\bigcirc$ \\
\hline ふくくらぎ & $\triangle$ & $\triangle$ & $\bigcirc$ \\
\hline
\end{tabular}

\section{4. 姿勢変更が下肢に与える影響を検証する実睃}

ノーマル姿勢とチルト姿勢で 15 分閒測定を行った.測定前

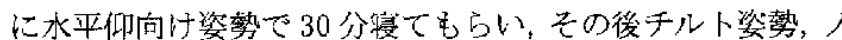
ーマル姿勢の順で测定完行った。 チルトの角度はノーマル姿 勢加ら $45^{\circ}$ 傾けた状態とした. また姿勢変更の合間はインタ 一バルとして 15 分問承平仰向け姿勢で寝てもらった。

被験者は健常者で仵齢 23(土1) [歳]の成人男性 4 人に対 L てそれぞれ 1 回測定した。室内の温湿度は、室内温度約 $25\left[{ }^{\circ} \mathrm{C}\right]\left( \pm 1\left[^{\circ} \mathrm{C}\right]\right)$ 、室内湿度䄪 $60[\%]( \pm 5[\%])$ で行った，実験 機器は先注どの水銀プレスチモグラフの他に被験者が座る車 い寸として GRAND FLETCHER を用いた。この車いすはリクライ ニング機能とチルト機能が搭載されている.

\section{1 実験結果と考察}

ノ一マル姿勢とチルト姿勢㭙における足肖の周囲径の時問 推移を Fig. 2 に示した. グラフの変化率の值注被験者のそれ ぞるの平均を取ったものである。

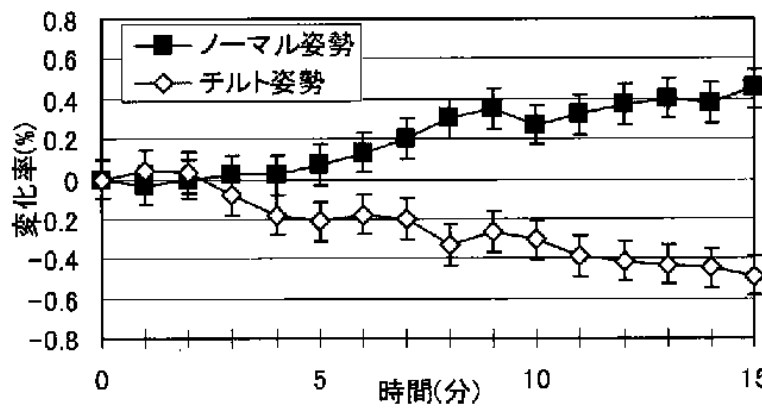

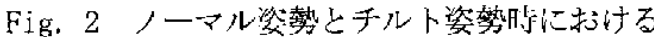
足首の周囲径の時間推移

Fig. 2小らわかる上うに15分という智时間でも是のむくみ は出てくる事がわかる，そして姿勢を変えるだけでむく加の 変化が見られることがわかった。今回はチルト筇勢比挍対 象としたが，これは㕠勢による心臟の高さと是首の高さとの 位画関係に着目している。チル姿勢で惊足の高さが心葴の 高さに近い位㯰にあるのでノーマル姿勢に対して血液やリン 八济が流れや手く，むくみにくくなるＦig. 2 からも足のむ く72の予防案の1つとして，チルト资勢は有效であるといら 事招実証された。しかし常にチル卜姿勢の状態を保つのはラ イフスタイルを考えても難しく，ノーマル姿勢の状態でチル 卜姿勢上同㥞の効果を得られる予防法を考案寸る必要がある。

\section{5. 今後の展望}

今後は今回上は違った姿勢による足のむくみの影響の検証 老行う予定である。交た被験者を実際の車い利用者に設定 して健常者との特性の比較を行う予定である。

\section{6. 去考文献}

1) Fumiharu Kimura, et al, Wheelchair economy class syndrome in amyotrophic lateral sclerosis, Neuromuscular Disorders 16(2006) 204-207 